\title{
Management of Intraneural Fibro-Lipoma of the Median Nerve and the Role of Pressure-Specified Sensory Device (PSSD) for the Patient's Motor and Sensorial Evaluations
}

\author{
Median Sinir Kökenli Intranöral Fibro-Lipomun Tedavisi ve Motor \\ ve Duyusal Fonksiyonların Değerlendirilmesinde Basınca Dayalı Duyu \\ Cibazınn Rolï
}

Celalettin SEVER ${ }^{1}$, Cihan SAHIN ${ }^{1}$, Yalcın BAYRAM ${ }^{2}$, Emin $\mathrm{KAPI}^{3}$, Yalcin KULAHCI ${ }^{1}$, Ufuk BERBER ${ }^{4}$, Mehmet INCEDAYI ${ }^{5}$, Fatih UYGUR ${ }^{1}$

${ }^{1}$ Gulhane Military Medical Academy, Haydarpasa Training Hospital, Department of Plastic and Reconstructive Surgery and Burn Unit, Istanbul, Turkey

${ }^{2}$ Maresal Cakmak Military Hospital, Department of Plastic and Reconstructive Surgery, Erzurum, Turkey

${ }^{3}$ Sirnak State Hospital, Department of Plastic and Reconstructive Surgery, Sirnak, Turkey

${ }^{4}$ Gulhane Military Medical Academy, Haydarpasa Training Hospital, Department of Pathology, Istanbul, Turkey

${ }^{5}$ Gulbane Military Medical Academy, Haydarpasa Training Hospital, Department of Radiology, Istanbul, Turkey

Correspondence address: Celalettin SEVER / E-mail: drcsever@hotmail.com

\begin{abstract}
AIM: The intraneural fibro-lipoma is a benign, uncommon tumor which is characterised with infiltration of the epineurium and perineurium by fibrofatty tissue. The preoperative diagnosis is difficult. However, the Pressure-Specified Sensory Device (PSSD) may support identifying the earliest stages of intraneural fibro-lipoma when traditional electrodiagnostic testing will not be able to detect a change in peripheral nerve function.

MATERIAL and METHODS: Five patients (3 male, 2 female, age 23-53; mean 41 years) with intraneural fibro-lipoma were operated on. Grip strength, pinch strength and sensorial functions were assessed in all patients before surgery and at the end of the follow-up period by PSSD.

RESULTS: The patients were followed-up for 7 to 24 months (mean; 12 month). All patient's condition improved dramatically following the operation and all patients had total relief of pain and paresthesia.

CONCLUSION: The decompression of intraneural fibro-lipoma of the nerve with limited excision and epineurotomy without sacrificing the main nerve and its branches is the ideal surgical procedure. We recommend the use of PSSD in the investigation of patients with peripheral nerve compression, and chronic unusual volar forearm and wrist swelling. PSSD is an important tool for pre-operative evaluation and diagnosis of intraneural fibro-lipoma.
\end{abstract}

KEYWORDS: Pressure-specified sensory device ( PSSD), Intraneural fibro-lipoma, Fatty infiltration

ÖZ

AMAÇ: Intranöral fibro-lipom, epinöryum ve perinöryumun, fibröz-yağ dokusu tarafından infiltre olmasıyla karakterize olan ve nadir görülen bir tümördür. Preoperatif tanısı zordur. Ancak, geleneksel testler ile periferik sinir fonksiyonlarının değerlendirilemediği intranöral fibrolipomun erken dönemlerinde 'Basınca Dayalı Duyu Cihazı' ( PSSD) tanının konulmasına yardımcı olmaktadır.

YÖNTEM ve GEREÇLER: 5 hasta (3erkek, 2 bayan, ortalama yaş 41) intranöral fibro-lipom tanısı ile opere edildi. Tüm hastaların cerrahi öncesinde ve takip periyodlarının sonunda PSSD ile kavrama ve sıkma kuvvetleri ve duyusal fonksiyonları değerlendirildi.

BULGULAR: Intranöral fibro-lipom, epinöryum ve perinöryumun, fibröz-yağ dokusu tarafından infiltre olmasıyla karakterize olan ve nadir görülen bir tümördür. Preoperatif tanısı zordur. Ancak, geleneksel testler ile periferik sinir fonksiyonlarının değerlendirilemediği intranöral fibro-lipomun erken dönemlerinde PSSD tanının konulmasına yardımcı olmaktadır.

SONUÇ: Intranöral fibro-lipomun sınırlı eksizyonla ve epinörotomi ile dekomprese edilmesi , ana sinir ve ana sinir dallarının bu işlem sırasında korunması en ideal cerrahi prosedürdür. Biz periferik sinir kompresyonu olan, uzun süredir kolunda ve önkol seviyesinde bir kitlesi olan hastaların tanısının araştııılmasında PSSD'yi önermekteyiz. PSSD, intranöral fibrolipomun preoperatif dönemde tanısında önemli bir rol oynamaktadır.

ANAHTAR SÖZCÜKLER: Basınca dayalı duyu cihazı, İntranöral fibrolipom, Yağ infiltrasyonu 


\section{INTRODUCTION}

The two most common nerve tumors in the upper extremity are Schwannoma and neurofibroma (20). Intraneural fibrolipoma of the nerve is a very rare, benign, slow-growing tumor and presents as an asymptomatic swelling. The tumor most commonly affects the median nerve and its branches $(2,12)$. It is usually found at birth or during infancy but most cases are diagnosed in childhood or early adulthood $(8,10,16,17)$. Some authors consider fibro-lipoma to be a congenital tumor, while other authors believe that this tumor is incited to grow by nerve irritation (13).

The fibrofatty elements of the fibro-lipoma infiltrate the perineurium and endoneurium. Perineural and endoneural fibrosis thickens the axonal bundles, which are interspersed through the proliferative fat. It may create a pathognomonic appearance on magnetic resonance imaging (MRI). Although diagnosis of the tumor with MRI may not be possible in every occasion, its MRI characteristics are considered as pathognomonic. The surgical procedure remains controversial and depends on the extent of nerve involvement. The decompression of the surrounding tissues, decompression and debulking of the fibrofatty sheath, microsurgical dissection and excision with or without cable grafts are the suggested treatment options for this rare tumor $(10,16)$. Herein, we report our case series of five patients and alert physicians to this rare form of intraneural tumor that requires early diagnosis and treatment.

\section{PATIENTS and METHODS}

This report included five patients ( 3 male, 2 female, age 3353; mean 41) who underwent electromyography (EMG), ultrasonography, and MRI to diagnose motor and sensory deficits in the territory of the affected nerve. In addition, grip strength and pinch strength were assessed in all patients before surgery and at the end of follow-up period by one examiner using the Pressure-Specified Sensory Device [(PSSD), Sensory Management Services, Baltimore, USA] (Figure $1 \mathrm{~A}-\mathrm{C}$ ). The final diagnosis was based on the history of dysesthesia, paraesthesia, and numbness in the median nerve distribution. The details of the patients are given in Table I.

Table I: The Demographic Properties of the Patients

\begin{tabular}{|c|c|c|c|c|}
\hline Patient No & Age (Year) & Gender & Location of tumor & Postoperative follow-up (months) \\
\hline 1 & 33 & Female & Median nerve Proximal forearm & 24 \\
\hline 2 & 42 & Male & $\begin{array}{l}\text { Median nerve } \\
\text { Right wrist }\end{array}$ & 7 \\
\hline 3 & 37 & Female & $\begin{array}{l}\text { Median nerve } \\
\text { Left wrist }\end{array}$ & 9 \\
\hline 4 & 53 & Male & $\begin{array}{l}\text { Median nerve } \\
\text { Proximal forearm }\end{array}$ & 10 \\
\hline 5 & 40 & Male & $\begin{array}{l}\text { Median nerve } \\
\text { Right wrist }\end{array}$ & 8 \\
\hline
\end{tabular}
and tourniquet control. In all patients, the nerve was yellow and pink with longitudinal fatty streaks within the nerve fibres and the median nerve was enlarged. There was thick epineurium that surrounded the nerves. The nerve was markedly swollen and incorporated in this mass. Excision of the infiltrated fatty tissues between the nerve fascicles was impossible due to the risk of causing neuronal injury. Epineurotomies were performed which revealed severely infiltrated fatty tissues and fibrosis between the nerve fascicles. When the epineurium was incised, fascicles were clearly discernible through an amorphous mass of whitishyellow tissue. Part of the mass was excised and the median nerve was left intact.

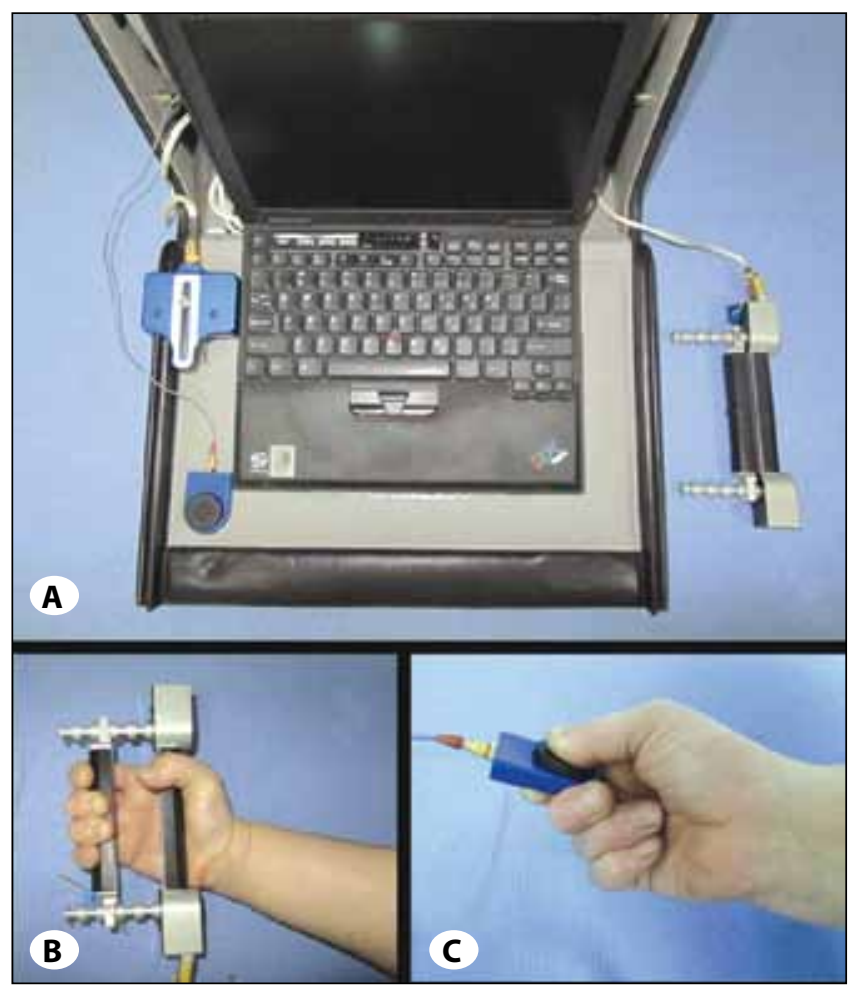

Figure 1: A) Pressure-Specified Sensory Device. B) The evaluation of grip strength. C) The evaluation of key pinch strength. patients were operated under regional block anesthesia 


\section{RESULTS}

All patient's condition improved dramatically following the operation and patients had total relief of pain and paresthesia. Pathologic confirmation was obtained for all patients previously diagnosed by means of radiological examination. The patients were followed-up for 7 to 24 months (mean; 12 months). There were no palpable masses, and the wounds healed well. No recurrence or injury to the neurovascular structures was noted in the follow-up period. Significant differences between the preoperative and postoperative periods were observed in either grip strength or pinch strength and are provided in Table II.

\section{CASE REPORTS}

\section{Case 1}

A 33-year-old female presented with a twenty-year history of progressive weakness of her right hand with some numbness. She had noticed a painless visible swelling in the proximal forearm (Figure 2). She had nocturnal paresthesia, and paresthesia in the right index, long and ring fingers. She had atrophy of the thenar muscles and clear signs of affection of the median nerve. MRI revealed displacement of the median nerve (Figure 3). Due to the MRI changes, clinical signs and the PSSD examination, the diagnosis was suggested as a fibro-lipoma of the median nerve. In the operation, an enormously enlarged median nerve infiltrated by fatty tissue

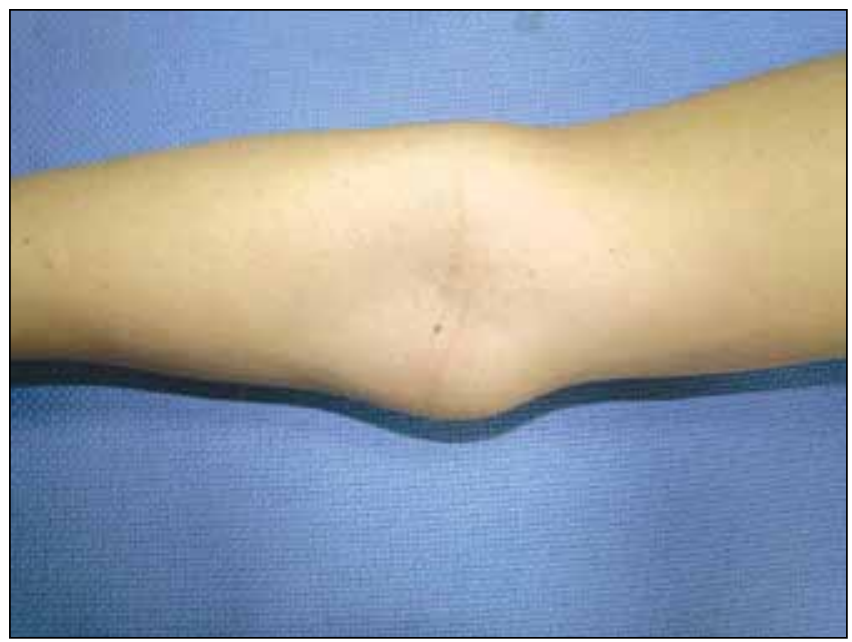

Figure 2: The painless visible mass in the proximal forearm. was observed (Figure 4). Excision of the tumor between the nerve fascicles was impossible without the risk of damage. Therefore, the nerve was left intact, and the operation was limited. Therefore, the tumor was left intact, and the operation was limited. Histological sections of the lesion confirmed the diagnosis of fibro-lipoma, which is a very rare entity (Figure 5). We have not encountered tumor recurrence during two
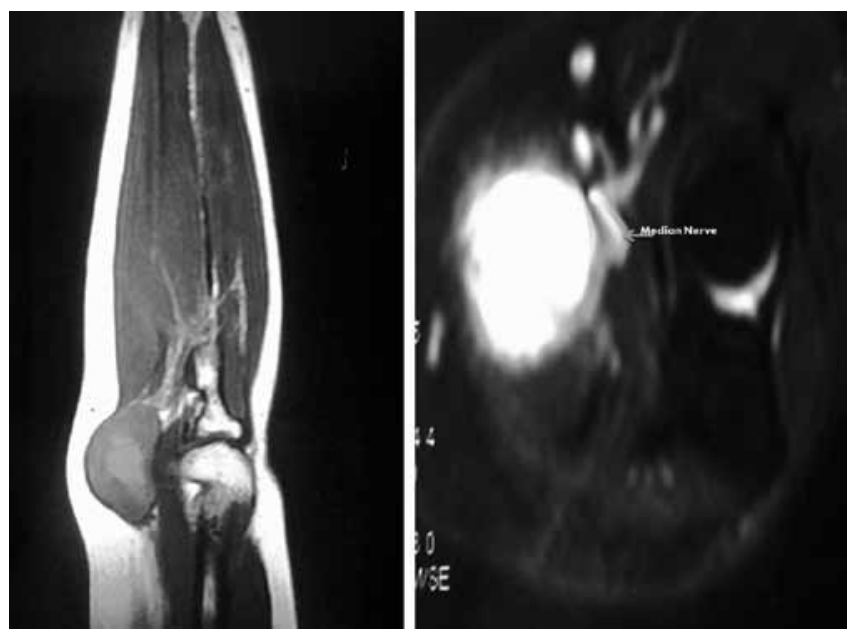

Figure 3: Magnetic resonance imaging (MRI) of the patient showing the displacement of median nerve by a fibro-lipoma at the elbow region.

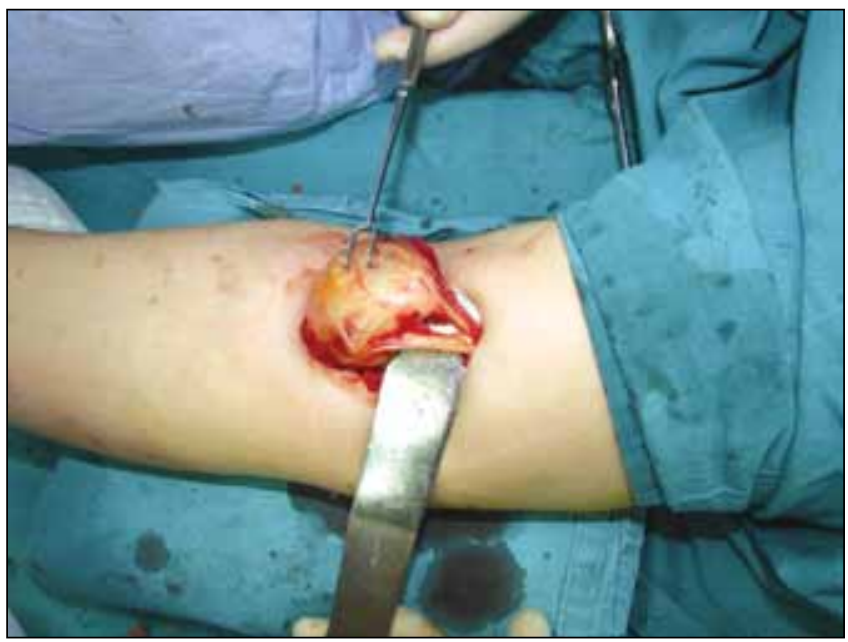

Figure 4: An enlarged median nerve infiltrated by intraneural fibro-lipoma.

Table II: Pre and Postoperative Scores for Grip Strength and Pinch Strength

\begin{tabular}{|c|c|c|c|c|} 
Patient No & $\begin{array}{c}\text { Preoperative GRIP } \\
\left(\mathbf{g} / \mathbf{~ m m}^{2}\right)\end{array}$ & $\begin{array}{c}\text { Postoperative GRIP } \\
\left(\mathbf{g} / \mathbf{~ m m}^{2}\right)\end{array}$ & $\begin{array}{c}\text { Preoperative PINCH } \\
\left(\mathbf{g} / \mathbf{~ m m}^{2}\right)\end{array}$ & $\begin{array}{c}\text { Postoperative PINCH } \\
\left(\mathbf{g} / \mathbf{m m}^{2}\right)\end{array}$ \\
\hline $\mathbf{1}$ & 16.7 & 22.4 & 2.8 & 6.4 \\
\hline $\mathbf{2}$ & 16.4 & 22.6 & 3.4 & 6.6 \\
\hline $\mathbf{3}$ & 15.2 & 23.8 & 3.1 & 5.8 \\
\hline $\mathbf{5}$ & 14.8 & 20.4 & 2.6 & 5.4 \\
\hline
\end{tabular}


years follow-up period and the physical examination of the patient demonstrated acceptable opposition function, pinch and grip strength.

\section{Case 4}

This male patient presented with a long-standing swelling over the volar aspect of the left forearm and paresthesia, in the middle finger of his non-dominant left hand. He had noticed the painless swelling for the past fifteen years. There was no palpable tenderness, obvious atrophy of the muscles, or loss of movement of the fingers. EMG and PSSD

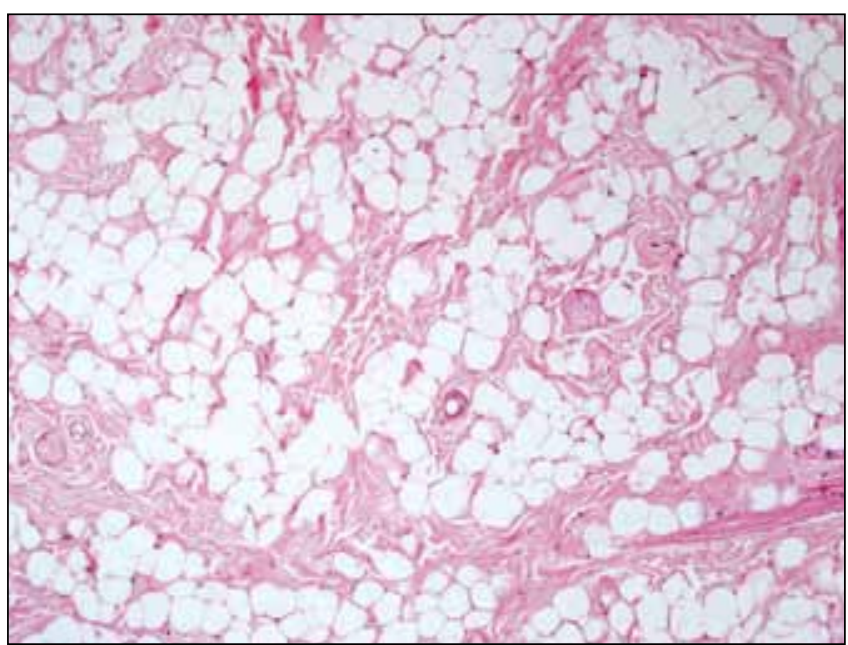

Figure 5: Biopsy show the presence of fibrofatty tissues around the nerve (H\&E stain, $\times 100)$. were performed. These investigations showed a severe loss of nerve fibres. Intraoperative findings confirmed a well circumscribed tumor of the median nerve. The nerve was insinuated with fibrous tissue and fat. Pathologic examination of the specimen reported as fibro-lipoma (Figure 6A-D). Ten months after surgery, the patient had marked improvement in his symptoms. The grip and the pinch strength of the left hand also improved and there was no increase in tumor size.

\section{Case 5}

This male patient was 40 years of age and right-hand dominant. He presented with a long-standing swelling over the volar aspect of the right wrist associated with numbness and weakness in the hand. He had noticed the painless swelling for the past ten years. Clinical examination revealed an obvious swelling over the volar aspect of the wrist extending from the distal-forearm to the region of the carpal tunnel. Tinel's sign and Phalen's test were positive for median nerve neuropathy. MR imaging showed fat displacing the fascicles of the median nerve. Intraoperative findings confirmed a well circumscribed tumor of the median nerve. The median nerve was markedly swollen and incorporated in this mass from a point $2 \mathrm{~cm}$. proximal to the volar carpal ligament. Histological sections of the lesion confirmed the diagnosis of fibrolipoma (Figure 7A-C). Eights months after surgery, the patient had marked improvement in his symptoms. The grip and the pinch strength of the right hand also improved and there was no increase in tumor size.

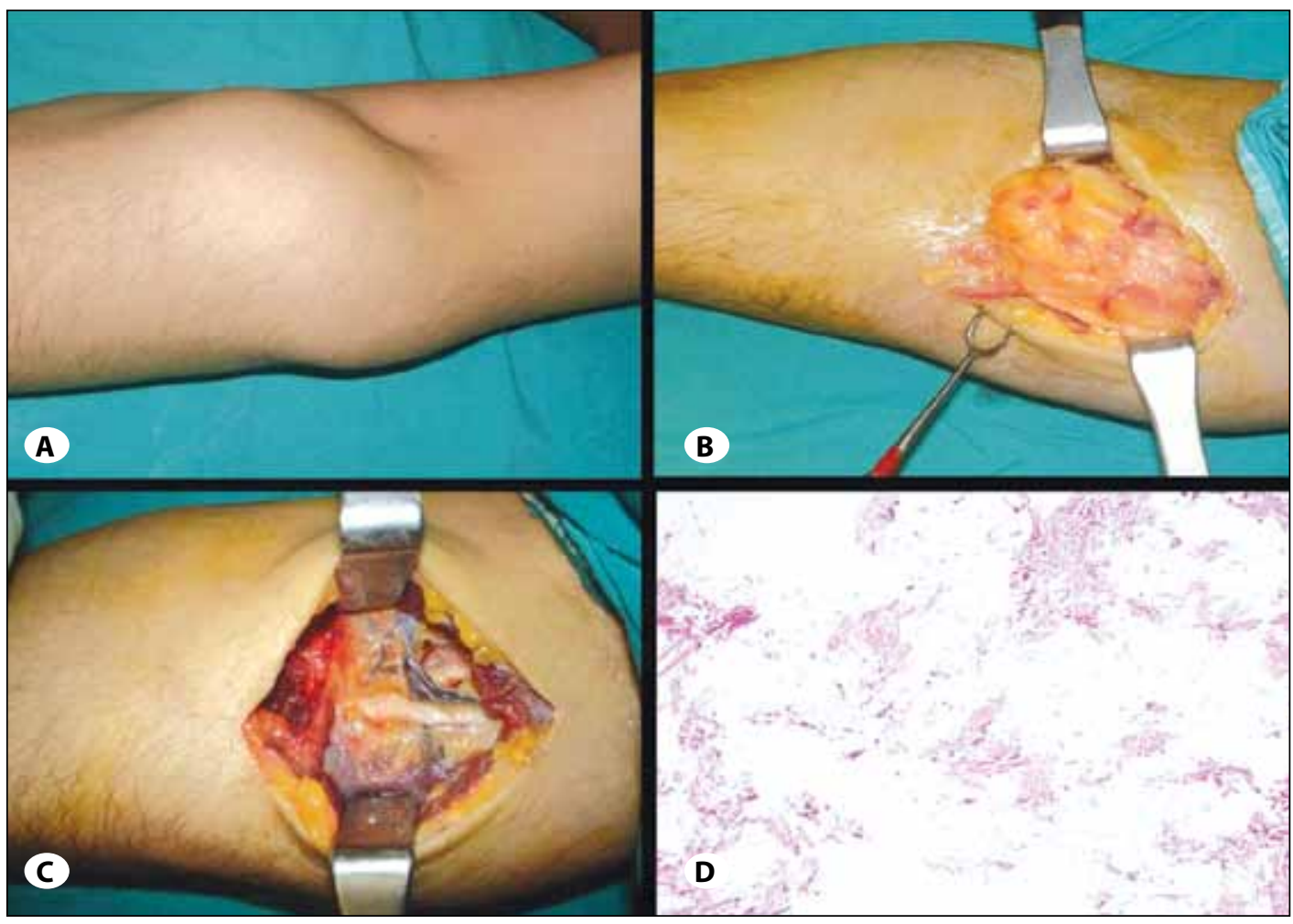

Figure 6: A 53-year-

old man with intraneural fibrolipoma of median nerve. A) Photograph shows swelling over the volar aspect of the proximal forearm. B) The intraoperative view. It illustrates typical gross appearance of fibrolipoma. C) The median nerve after neurolysis. D) Microscopic view of fibro-lipoma. The lesion mostly consists of mature adipose tissue. In between the fat cell groups, collagenous connective tissue component is also seen (H\&E stain, $\times 40)$. 


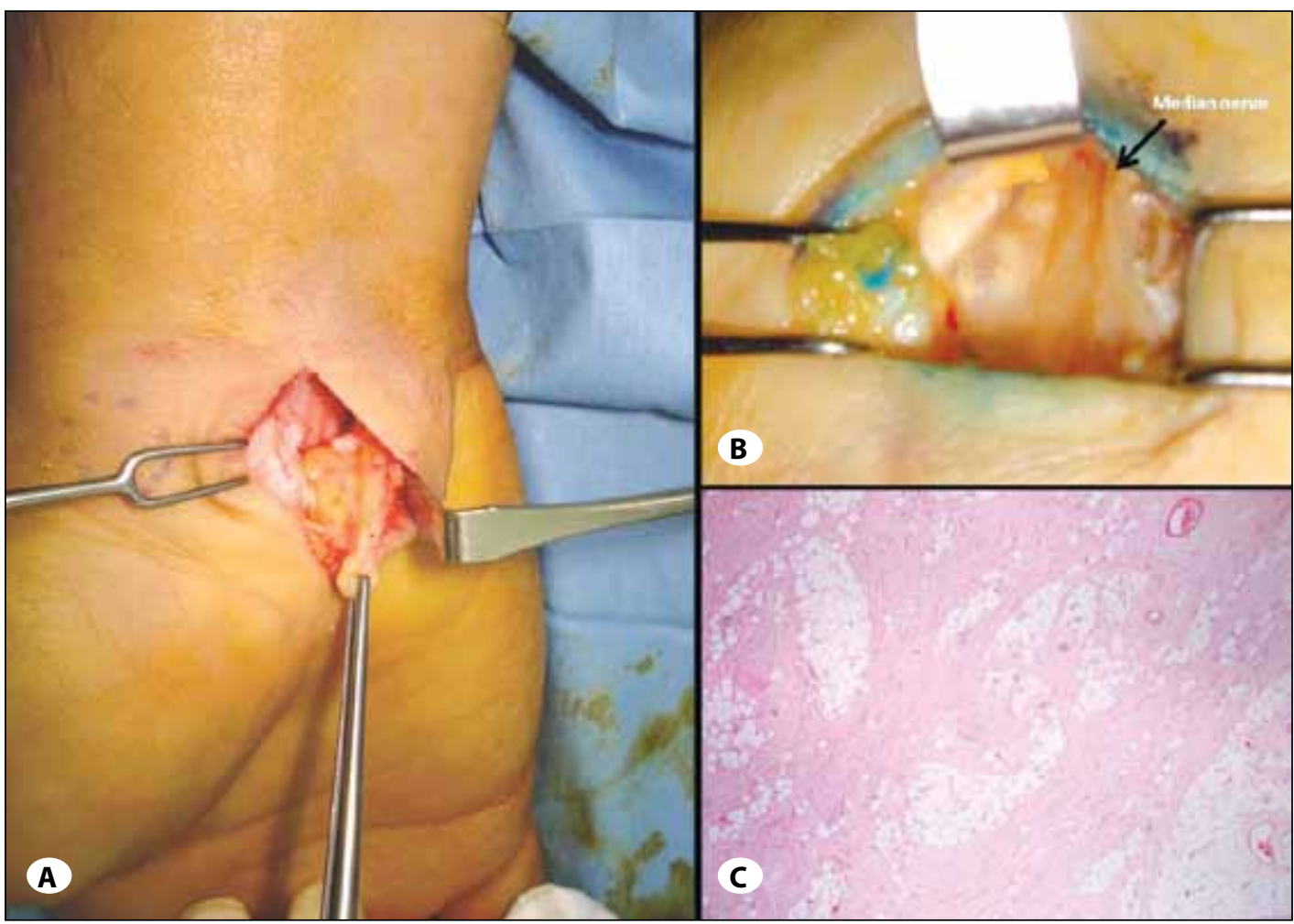

Figure 7: A) The intraoperative view of intraneural fibrolipoma of median nerve at wrist level. B) The median nerve after neurolysis.

C) Microscopic view of fibro-lipoma. (H\&E stain, $\times 40$ ).

\section{DISCUSSION}

Intraneural fibro-lipoma is a rare benign tumor that most commonly affects the peripheral nerves, most commonly in the upper extremities. Distal peripheral lesions occur rather than proximal lesions. Although benign, it generally progresses, leading to the loss of function of the nerve. The condition has also been called as fibrolipomatous nerve enlargement, lipofibroma, fibro-fatty proliferation, fibro-fatty overgrowth, fatty infiltration $(1,3,6,9)$. At present, the term 'intraneural fibro-lipoma' seems to be preferred, because it best reflects the nature of the tumor (25).

The etiology of intraneural fibro-lipoma is unclear, although several etiologic theories have been described. The congenital or developmental origin is the first theory because the condition is most common among white people. In addition, it occurs sporadically across populations. Another theory is that the lesion may be caused by trauma, nerve irritation or inflammation $(3,13)$.

Patients with intraneural fibro-lipoma usually present in the third to fourth decades of life (9). Most cases present with a long standing painless mass. Associated clinical symptoms include paresthesia, motor deficit and pain, along with motor and sensory deficits in the territory of the affected nerve. Neurological symptoms generally relate to compression, carpal tunnel syndrome for median nerves, and cubital tunnel syndrome for ulnar nerves $(6,9,11,25)$.

The differential diagnoses of a median nerve mass include intraneural lipoma, ganglion cyst, diffuse lipomatosis, traumatic neuroma, schwannoma, fibromatosis, tenosynovitis, hemangioma and vascular malformation (3). A diagnosis is usually made based on patient's history and clinical examination. MRI imaging is an important tool for pre-operative evaluation and diagnosis. MRI characteristics of intraneural fibro-lipoma are pathognomonic which is helpful to exclude other diagnoses. The pathognomonic findings in the median nerve consist of an enlarged nerve. Ultrasonography may be helpful to show enlarged nerve appearance of the nerve with hyperechoic and hypo- echoic bands $(6,9,11,14,25)$. Electromyography may provide valuable information needed to confirm a diagnosis. It may show prolonged distal latency of sensory or motor innervation and fibrillations in distal muscles to confirm a compressive neuropathy.

Fibrolipoma of the median nerve may present late with advanced signs of compressive neuropathy. For this reason, in this report, we measured the grip strength, key pinch and sensorial evaluations in all patients before and after the surgery by using the Pressure-Specified Sensory Device (PSSD). Because neurosensory testing with PSSD offers advantages over traditional electrodiagnostic studies. The PSSD will identify the earliest stages of intraneural fibrolipoma when traditional electrodiagnostic testing will not be able to detect a change in peripheral nerve function, and therefore the PSSD will correlate better with patient symptoms $(4,5)$. We recommend the use of PSSD in the investigation of young patients with peripheral nerve compression, and concomitant chronic unusual volar forearm and wrist swelling that is not typical of synovitis or a cystic lesion. 
It has been reported that all patients with abnormal electrodiagnostic testing had abnormal quantitative sensory testing with the PSSD. Those patients with clinically significant peripheral nerve compression who had normal electrodiagnostic testing had abnormal quantitative sensory testing with PSSD. Another advantage is that the results of electrodiagnostic testing often do not predict the success of surgery for chronic nerve entrapment. For many common peripheral nerve problems, such as chronic nerve compression, the high cost of the electrodiagnostic test, its invasive nature, the pain associated with it, and the frequent lack of correlation between the patient's symptoms and the test are all reason for us to use low-cost, quantitative sensorimotor testing $(4,19,21,24)$.

Electrodiagnostic testing almost never demonstrates a proximal median nerve compression in the forearm. Dellon stated that about $50 \%$ of the patients with symptoms an clinical findings compatible with ulnar nerve compression have normal electrodiagnostic studies (4). In addition, it is extremely difficult to demonstrate radial sensory nerve compression with normal electrodiagnostic studies (4). The PSSD meets all the criteria of the consensus reports of the American Diabetes Association and the American Peripheral Neuropathy Association for quantitative sensory testing (5).

The surgical treatment of intraneural fibro-lipoma is highly controversial. There are various treatment options for intraneural fibro-lipoma: observation, decompression, intraneural neurolysis, and excision of tumor with or without nerve grafting. The complete excision of tumor may provide a cure. However, complete excision of an intraneural tumor may not be feasible due to the extensive fatty infiltration of the nerve fascicles $(7,12,15,18)$. The complete excision may give rise catastrophic motor and sensory deficits. Silverman and Enzinger reported that patients who underwent complete excision experienced severe motor and sensory deficits (22).

\section{CONCLUSION}

The intraneural fibro-lipoma of the nerve presents with advanced signs and symptoms of compressive neuropathy. For this reason, the early diagnosis of intraneural fibro-lipoma is so important. When traditional electrodiagnostic testings and ultrasonography fail to reveal the nerve compression in the early stage, PSSD may be more helpful. PSSD may reveal a high suspicion of the diagnosis of intraneural fibro-lipoma. In advanced diseases, decompression with limited excision and epineurotomy without sacrificing the main nerve and its branches is the ideal surgical procedure.

\section{REFERENCES}

1. Anoush Razzaghi, Dimitri J: Anastakis. Lipofibromatous hamartoma: Review of early diagnosis and treatment. Can J Surg 48(5):394-399, 2005

2. Camilleri IG, Milner RH: Intraneural lipofibroma of the median nerve. J Hand Surg Br 23:120 - 122, 1998

3. So CK, Tam KF, Lui CY, Lee CM: Fibrolipomatous hamartoma of the median nerve. J HK Coll Radiol 10:81-84, 2007
4. Dellon AL: Electrodiagnostic testing, in Somatosensory Testing and Rehabilitation, Dellon $\mathrm{AL}$, ed, Baltimore, Maryland: Chapter 8, 2000:178-183

5. Dellon AL: Instrumentation: The Pressure-Specified Sensory Device, in Somatosensory Testing and Rehabilitation, Dellon AL, ed. Baltimore, Maryland: Chapter 7, 2000:130-142

6. De Maeseneer M, Jaovisidha S, Lenchik L, Witte D, Schweitzer ME, Sartoris DJ, Resnick D: Fibrolipomatous hamartoma: MR imaging findings. Skeletal Radiol 26:155-160, 1997

7. Flores LP, Carneiro JZ: Peripheral nerve compression secondary to adjacent lipomas. Surg Neurol 67: 258 - 263, 2007

8. Frykman GK, Wood VE: Peripheral nerve hamartoma with macrodactyly in the hand: Report of three cases and review of the literature. J Hand Surg (Am) 3:307-312, 1978

9. Guthikonda M, Rengachary SS, Balko MG, van Loveren $\mathrm{H}$ : Lipofibromatous hamartoma of the median nerve: Case report with magnetic resonance imaging correlation. Neurosurgery 35:127-132, 1994

10. Johnson RJ, Bonfiglio M: Lipofibromatous hamartoma of the median nerve. J Bone Joint Surg (Am) 51:984-990, 1969

11. Khanna G, Sundaram M, Rotman M, Janney CG: Fibrolipomatous hamartoma of the nerve. Orthopedics 24:919-820, 2001

12. Louis DS, Hankin FD, Greene TL, Dick HM: Lipofibromatous of the median nerve: Long-term follow- up of four cases. J Hand Surg Am 10: 403 - 408, 1985

13. Marom EM, Helms CA: Fibrolipomatous hamartoma: Pathognomonic on MR imaging. Skeletal Radiol 28:260-264, 1994

14. Nardella D, Sohawon S, Carlier A: Lipofibromatous hamartoma of the median nerve. Three case reports. J Plast Reconstr Aesthet Surg 62: e314 - e317, 2009

15. Nouira K, Belhiba H, Baccar S, Miaaoui A, Ben Messaoud M, Turki I, Cheour I, Menif E: Fibrolipoma of the median nerve. Joint Bone Spine 74: 98 - 99, 2007

16. Paletta FX, Senay LC Jr: Lipofibromatous hamartoma of median nerve and ulnar nerve: Surgical treatment. Plast Reconstr Surg 68:915-921, 1998

17. Patel ME, Silver JW, Lipton DE, Pearlman HS: Lipofibroma of the median nerve in the palm and digits of the hand. J Bone Joint Surg Am 61: 393 - 397, 1979

18. Price AJ, Compson JP, Calonje E: Fibrolipomatous hamartoma of nerve arising in the brachial plexus. J Hand Surg $\mathrm{Br} 20$ : 16-18, 1995

19. Rosson GD, Rodriguez ED, George P, Dellon AL: Surgical algorithm for treatment of post-traumatic trigeminal nerve pain. Microsurgery 30(8):614-621, 2010

20. Sandberg K, Nilsson J, Soe Nielsen N, Dahlin LB: Tumours of peripheral nerves in the upper extremity: A 22-year epidemiological study. Scand J Plast Reconstr Surg Hand Surg 43: 43-49, 2009

21. Sever C, Kulahci Y, Oksuz S, Sahin C: The mini incision technique for carpal tunnel decompression using nasal instruments. Turk Neurosurg 20(3):353-357, 2010

22. Silverman TA, Enzinger FM: Fibrolipomatous hamartoma of nerve. A clinicopathologic analysis of 26 cases. Am J Surg Pathol 9(1):7-14, 1985 
23. Uygur F, Sever C, Yuksel F: Comparing the results of limited incision technique and standard longitudinal incision technique for carpal tunnel decompression by numerical grading system. Turk Neurosurg 19(1):51-57, 2009

24. Wolfort SF, Dellon AL: Peripheral neuropathy in HIV patients: Treatment by decompression of peripheral nerves. Microsurgery 32(1):31-34, 2012

25. Yamauchi T, Yoshii T, Sempuku T: Whether to excise a lipofibroma of the median nerve. Scand J Plast Reconstr Surg Hand Surg 43(6):346-349, 2009 